\title{
REVIEW
}

\section{Protein security and food security in China}

\author{
Zheng RUAN (凶) $)^{1,2}$, Shumei MI ${ }^{1,2}$, Yan ZHOU ${ }^{1,2}$, Zeyuan DENG ${ }^{1,2}$, Xiangfeng KONG ${ }^{3}$, \\ Tiejun $\mathrm{LI}^{3}$, Yulong YIN (凶) $)^{1,2,3}$ \\ 1 School of Food Science and Technology, Nanchang University, Nanchang 330031, China \\ 2 State Key Laboratory of Food Science and Technology, Nanchang University, Nanchang 330047, China \\ 3 Institute of Subtropical Agriculture, Chinese Academy of Sciences, Changsha 410125, China
}

\begin{abstract}
Food security, the need to meet nutritional requirements, and four main problems for food protein security in China are analyzed. From the perspective of residents' nutritional requirements and balanced dietary patterns, the conclusion is that food security in China is in essence dependent on protein production and security of supply and that fat and carbohydrates supply in China can reach self-sufficiency. Considering the situation of food protein production and consumption in China, policy suggestions are made, which could ensure a balanced supply and demand for food protein and food security in China.
\end{abstract}

Keywords food security, protein security, nutrition, dietary pattern

\section{Current situation of food security}

1.1 Food is the precondition and foundation for human survival and development

Food security is the precondition for human survival and development, the foundation for national economic and social development, as well as the basic constraint for the existence and development of human society ${ }^{[1]}$. Under the basic self-sufficient food security policy, increased grain production has become the primary goal that the agricultural management and production departments in China have been aiming to achieve. With the increase in population, the improvement in economic conditions, and the changes in dietary patterns in China, food demand will

Received April 20, 2015; accepted June 26, 2015

Correspondences: ruanzheng@ncu.edu.cn, yinyulong@isa.ac.cn continue to expand ${ }^{[2]}$. The constraints of resource and environment, however, restrict the further increase of grain yield. Therefore, it is of significant importance, in both theory and reality, to establish scientific and reasoned approaches so that food production and food consumption match each other by formulating an appropriate food qualitative and quantitative targets based on the human nutritional requirements.

\subsection{Food and nutritional requirements}

Food contains the nutrients that meet the needs of the human body. Proteins, fat, carbohydrates, water, vitamins and minerals are the six major nutrient groups. Among them, proteins, fat and carbohydrates are the main constituents and energy supplying materials for the activities of living cells, and their requirements are substantial, whereas vitamins and minerals are needed in only trace amounts. China is rich in resources and is completely able to meet its current and future nutritional requirements.

Fat comes mainly from vegetable oil and animal fat. In terms of nutritional requirements of fat, the people in mainland China need about $28 \mathrm{Mt}$ of fat (Table 1). Edible fat and oil consumption in China has increased from 13.5 $\mathrm{Mt}^{[5]}$ in 2000 to $30.4 \mathrm{Mt}$ in 2013, which shows the trend in China and a shift from an inadequate intake of oil and fat to a state of excessive consumption. In the past decade or so, the large imports of oil and oil plants have seriously inhibited domestic edible oil production using squeezing/ extracting techniques ${ }^{[6]}$. In 2013, China's vegetable oil production was about $14 \mathrm{Mt}$, while the production of edible oilseeds reached up to $58 \mathrm{Mt}^{[7]}$, which was equivalent to about $19 \mathrm{Mt}$ of vegetable oil (Table 2). In addition, the availability of animal fat was about $8.7 \mathrm{Mt}$ in 2000 (supplies of pork, beef and mutton were $47 \mathrm{Mt}$, and eggs were $21 \mathrm{Mt}^{[8]}$, when the amount of soybean meal 
Table 1 The requirements of main nutrients (proteins, fat and carbohydrates)

\begin{tabular}{|c|c|c|c|c|c|c|c|c|}
\hline \multirow[b]{2}{*}{$\begin{array}{l}\text { Age } \\
\text { (years old) }\end{array}$} & \multirow[b]{2}{*}{$\begin{array}{l}\text { Population }{ }^{\mathrm{a}} \\
\text { (ten thousand) }\end{array}$} & \multirow[b]{2}{*}{$\begin{array}{c}\text { Average } \\
\text { weight } / \mathrm{kg}\end{array}$} & \multicolumn{2}{|c|}{ Protein requirements ${ }^{\mathrm{b}}$} & \multicolumn{2}{|c|}{ Fat requirements } & \multicolumn{2}{|c|}{ Carbohydrate requirements } \\
\hline & & & $\begin{array}{l}\text { Average require- } \\
\text { ments per person } \\
\quad \text { each day/g }\end{array}$ & $\begin{array}{l}\text { Annual total } \\
\text { requirements/kt } \\
\quad(\times 10)\end{array}$ & $\begin{array}{l}\text { Average require- } \\
\text { ments per person } \\
\text { each day/g }\end{array}$ & $\begin{array}{l}\text { Annual total } \\
\text { requirements } \\
/ \mathrm{kt}(\times 10)\end{array}$ & $\begin{array}{l}\text { Average require- } \\
\text { ments per person } \\
\text { each day/g }\end{array}$ & $\begin{array}{l}\text { Annual total } \\
\text { requirements/kt } \\
\quad(\times 10)\end{array}$ \\
\hline$\overline{0}$ & 1378.64 & 7.85 & 22.32 & 11.23 & 19.84 & 9.99 & 111.62 & 56.17 \\
\hline 1 & 2311.92 & 9.63 & 24.45 & 20.63 & 21.73 & 18.34 & 122.26 & 103.17 \\
\hline 2 & 2412.51 & 12.09 & 31.02 & 27.31 & 27.57 & 24.28 & 155.10 & 136.57 \\
\hline 3 & 2352.33 & 14.38 & 35.10 & 30.13 & 31.20 & 26.79 & 175.48 & 150.67 \\
\hline 4 & 2346.62 & 16.36 & 38.52 & 33.00 & 34.24 & 29.33 & 192.61 & 164.98 \\
\hline 5 & 2272.03 & 18.22 & 41.56 & 34.47 & 36.95 & 30.64 & 207.82 & 172.34 \\
\hline 6 & 2283.89 & 20.2 & 44.76 & 37.31 & 39.78 & 33.16 & 223.78 & 186.55 \\
\hline $7-9$ & 4134.49 & 25.25 & 52.20 & 78.77 & 46.40 & 70.02 & 260.98 & 393.85 \\
\hline $10-12$ & 4378.96 & 36.20 & 66.33 & 106.01 & 58.96 & 94.23 & 331.63 & 530.04 \\
\hline $13-15$ & 4914.33 & 50.34 & 80.91 & 145.12 & 71.92 & 129.00 & 404.53 & 725.61 \\
\hline $16-18$ & 6032.12 & 61.28 & 85.22 & 187.63 & 75.75 & 166.78 & 426.09 & 938.13 \\
\hline 19-64 & 91421.54 & 62.00 & 66.41 & 2215.90 & 59.03 & 1969.69 & 332.03 & 11079.50 \\
\hline Above 65 & 11892.72 & 60.84 & 57.03 & 247.56 & 50.69 & 220.06 & 285.16 & 1237.82 \\
\hline Total & 133281.11 & & & 3175.08 & & 2822.29 & & 15875.39 \\
\hline
\end{tabular}

Note: ${ }^{a}$ The population data comes from the Sixth National Population Census ${ }^{[3]}$, which only included Mainland China; ${ }^{\mathrm{b}}$ proteins provide $10 \%-15 \%$ of the total calories, and the median value of $12.5 \%$ was used; fat provides $25 \%$ of the total calories, while carbohydrates provide $60 \%-65 \%$, and the median value of $62.5 \%$ was used $^{[4]}$.

Table 2 Oil and fat consumption in China (2013)

\begin{tabular}{|c|c|c|c|c|c|c|}
\hline \multirow{2}{*}{ Type } & \multirow{2}{*}{ Source } & \multicolumn{3}{|c|}{ Yield/kt $(\times 10)$} & \multicolumn{2}{|c|}{ Consumption/kt $(\times 10)$} \\
\hline & & Fat content & Domestic resource & Import & Population & Livestock and poultry \\
\hline \multirow{10}{*}{ Vegetable oil } & Soybean oil & & 251 & 1535 & 1140 & 105 \\
\hline & Rapeseed oil & & 614 & 153 & 580 & / \\
\hline & Palm oil & & 1 & 598 & 428 & 230 \\
\hline & Peanut oil & & 252 & 6 & 246 & I \\
\hline & Sunflower seed oil & & 50 & 75 & 100 & 25 \\
\hline & Corn oil & & 72 & 148 & 72 & I \\
\hline & Tea-seed oil & & 45 & l & 45 & l \\
\hline & Cottonseed oil & & 118 & 1 & 30 & 30 \\
\hline & Sesame oil & & 25 & 10 & 20 & / \\
\hline & Total & & 1428 & 2525 & 2661 & 390 \\
\hline \multirow{7}{*}{ Animal fat } & Egg & $8.8 \%$ & 2876 & / & 254 & \\
\hline & Milk & $3.4 \%$ & 3531 & 20 & 163 & \\
\hline & Fish & $2.5 \%$ & 3160 & 417 & 82 & \\
\hline & Pork & $28.0 \%$ & 5493 & 58 & 1473 & \\
\hline & Beef & $10.2 \%$ & 673 & 29 & 61 & \\
\hline & Mutton & $14.1 \%$ & 408 & 26 & 57 & \\
\hline & Total & & 16141 & 550 & 2090 & \\
\hline
\end{tabular}

Note: Domestic production includes that made in Mainland China and import means the sum of the oil directly imported to Mainland China and the oil quantity converted from imported oil seeds.

made from imported soybeans and used to feed livestock was less than $7 \mathrm{Mt}$ ). After taking into account a loss rate of
$5 \%$, the sum could reach $26.6 \mathrm{Mt}$, which would be $94.3 \%$ of the fat requirements of the population. Thus, from the 
perspective of dietary patterns and nutritional requirements, the domestic production oil plants can basically meet Chinese edible oil requirement.

Carbohydrates are the main nutrients that supply energy. They occur extensively in rice, wheat, corn, tuberous crops and bean crops. In 2013, the food production in China included grain production of $601 \mathrm{Mt}^{[9]}$, which contains $400 \mathrm{Mt}$ of carbohydrates, and about $201 \mathrm{Mt}^{[10]}$ of carbohydrates used for human consumption. In terms of the total nutritional requirements, the people in Mainland China needed about $159 \mathrm{Mt}$ of carbohydrates per year, and the domestic grain production can meet this need now and for the next 20 years (Table 1 ). The proportion of China's food consumption to total grain consumption decreased gradually by $51 \%$ between 1995 and 2008, reaching $268 \mathrm{Mt}$ in 2008. The growth of grain used for animal feed is the main reason for the increase of grain consumption in China, with the proportion reaching $34 \%$ in 2009 , and grain for industrial uses accounting for $15 \%{ }^{[11]}$. While the proportion of grain imports in gross production was less than $3 \%{ }^{[12]}$. These data illustrate that China's supply of carbohydrates can perfectly ensure the nutritional requirements of its population.

Proteins are indispensable for sustaining life, and mainly come from meat, eggs, milk, fish, beans, wheat and corn (Table 3). Based on the required protein intake, which also provides $12.5 \%-15 \%$ of the total calories, the preliminarily estimate of the protein requirement of the Chinese population is 31.8 to $38.1 \mathrm{Mt}$ in 2013 (Table 1). In 2013, protein consumption in China was $46.3 \mathrm{Mt}$ (equivalent to the recommended dietary protein, Table 4 ) and the current supply of protein was lower than the protein requirement based on a healthy target. Secondly, lysine, methionine, threonine and tryptophan in plant-derived proteins occur in relatively low proportions, which means the supply of these amino acids from plant sources is restricted and must be supplemented by animal-based foods ${ }^{[13]}$. Currently vegetable protein $(2.5 \mathrm{Mt})$ and animal protein $(9.0 \mathrm{Mt})$ available in China come from imported meat products or are indirectly produced from imported agricultural products, including imported soybeans (63 Mt). The country's self-sufficiency rate of edible proteins is $73.1 \%$ (Table 5), and the self-sufficiency rate for protein feeds is about $52.6 \%$. Imported agricultural products can have a competitive price advantage over domestic agricultural products. Therefore, from the perspective of nutritional requirements and food quality, the grain security issue is, in essence, dependent on protein production and supply.

\section{Problems concerning China's food security and protein security}

People are the foundation of a nationality, food is the basic requirement of the people. China's total grain production has been increasing for ten consecutive years, which lays a solid foundation for ensuring the national grain security and stabilizing the economic development. However, considering the large population and relatively scarce agricultural land in China, the total agricultural resources

Table 3 Protein source for China (2013)

\begin{tabular}{|c|c|c|c|c|c|c|c|c|}
\hline & \multirow{2}{*}{ Source } & \multirow{2}{*}{ Protein content } & \multicolumn{2}{|c|}{ Total $/ \mathrm{kt}(\times 10)$} & \multicolumn{2}{|c|}{ Population consumption/kt $(\times 10)$} & \multicolumn{2}{|c|}{ Livestock consumption/kt $(\times 10)$} \\
\hline & & & Domestic & $\overline{\text { Imported }}$ & Food & Protein & Feed & Protein \\
\hline \multirow[t]{9}{*}{ Vegetable protein } & Rice & $8.5 \%$ & 20308 & 227 & 16190 & 1376 & 1690 & 144 \\
\hline & Wheat & $14.0 \%$ & 10490 & 553 & 8275 & 1159 & 1525 & 214 \\
\hline & Corn & $11.0 \%$ & 20020 & 327 & 1360 & 150 & 15400 & 1694 \\
\hline & Potato & $2.3 \%$ & 8893 & 4 & 5783 & 133 & 1512 & 35 \\
\hline & Soybean & $35.0 \%$ & 1256 & 6338 & 938 & 328 & l & l \\
\hline & Bean pulp & $42.0 \%$ & 992 & 5153 & l & l & 5220 & 2193 \\
\hline & Rapeseed meal & $36.0 \%$ & 1105 & 20 & l & l & 638 & 230 \\
\hline & $\begin{array}{c}\text { Cotton seed } \\
\text { meal }\end{array}$ & $44.0 \%$ & 437 & 127 & l & l & 375 & 165 \\
\hline & Total & l & 63601 & 12749 & 32546 & 3146 & 26360 & 4675 \\
\hline \multirow[t]{7}{*}{ Animal protein } & Egg & $13.3 \%$ & 2020 & 863 & 2883 & 383 & l & l \\
\hline & Milk & $3.3 \%$ & 3531 & 20 & 3538 & 117 & I & 1 \\
\hline & Fish & $18.5 \%$ & 3160 & 417 & 3277 & 606 & l & I \\
\hline & Pork & $13.2 \%$ & 2498 & 3053 & 5262 & 695 & I & I \\
\hline & Beef & $20.0 \%$ & 673 & 29 & 659 & 132 & I & I \\
\hline & Mutton & $19.0 \%$ & 408 & 26 & 406 & 77 & l & I \\
\hline & & 1 & 13603 & 3545 & 16025 & 2010 & 1 & 1 \\
\hline
\end{tabular}

Note: Protein contents are mean values for all kinds of food. 
Table 4 Edible dietary protein for Chinese (2013)

\begin{tabular}{|c|c|c|c|c|c|c|c|c|c|}
\hline & Type & $\begin{array}{c}\text { Consumable } \\
\text { Protein } / \text { kt }(\times 10)\end{array}$ & Loss rate & $\begin{array}{c}\text { Dietary protein for } \\
\text { population } / \mathrm{kt}(\times 10)\end{array}$ & & Type & $\begin{array}{c}\text { Consumable } \\
\text { Protein } / \mathrm{kt}(\times 10)\end{array}$ & Loss rate & $\begin{array}{c}\text { Dietary protein for } \\
\text { population } / \mathrm{kt}(\times 10)\end{array}$ \\
\hline \multirow{7}{*}{$\begin{array}{l}\text { Vegetable } \\
\text { protein }\end{array}$} & Rice & 1376 & $20 \%$ & 1101 & \multirow{7}{*}{$\begin{array}{l}\text { Animal } \\
\text { protein }\end{array}$} & Egg & 383 & $12.5 \%$ & 335 \\
\hline & Wheat & 1159 & $20 \%$ & 927 & & Milk & 117 & $5 \%$ & 111 \\
\hline & Corn & 150 & $20 \%$ & 120 & & Fish & 606 & $15 \%$ & 515 \\
\hline & Potato & 133 & $20 \%$ & 106 & & Pork & 695 & $12 \%$ & 612 \\
\hline & \multirow[t]{2}{*}{ Soybean } & \multirow[t]{2}{*}{328} & \multirow[t]{2}{*}{$20 \%$} & \multirow[t]{2}{*}{262} & & Beef & 132 & $12 \%$ & 116 \\
\hline & & & & & & Mutton & 77 & $12 \%$ & 68 \\
\hline & Total & & & 2516 & & Total & 2010 & & 1757 \\
\hline \multicolumn{5}{|c|}{$\begin{array}{l}\text { Recommended dietary } \\
\text { protein } / \mathrm{kt}(\times 10)\end{array}$} & 4273 & & & & \\
\hline
\end{tabular}

Note: The value of loss rate were adopted according to mean estimated value.

Table 5 Supply and requirement of protein in China ${ }^{a}$

\begin{tabular}{|c|c|c|c|c|c|c|c|}
\hline \multirow{2}{*}{ Type } & \multirow{2}{*}{ Amount/kt $(\times 10)$} & \multicolumn{4}{|c|}{ Requirement ${ }^{\mathrm{b}} / \mathrm{kt}(\times 10)$} & \multicolumn{2}{|c|}{ Supply rate/\% } \\
\hline & & $2013^{*}$ & $2013^{\#}$ & $2030^{*}$ & $2030^{\#}$ & $2013^{*}$ & $2030^{\#}$ \\
\hline Consumption & 4273 & 3175 & 3810 & 3617 & 4340 & 134.6 & 98.5 \\
\hline Domestic resource & 3122 & & & & & 98.3 & 71.9 \\
\hline Imported resource & 1151 & & & & & 36.3 & 26.5 \\
\hline Potential by techniques & 927 & & & & & 29.2 & 21.4 \\
\hline Prediction $^{\mathrm{c}}$ & 4049 & & & & & 127.5 & 93.3 \\
\hline Max domestic potential $^{\mathrm{d}}$ & 4850 & & & & & 152.8 & 111.8 \\
\hline
\end{tabular}

Note: ${ }^{\mathrm{a}}$ The population data comes from the Sixth National Population Census, which included only Mainland China ${ }^{[3]}{ }^{\mathrm{b}}$ the population is estimated to be 1.515 billion in $2030 ;{ }^{c}$ the predicted supply was calculated based on the sum of domestic and potential yield in 2013 from processing and preserving techniques; ${ }^{\mathrm{d}}$ the value is estimated based on land and sea resources of Mainland China in 2025 assuming that food and agricultural products from oversea cannot be imported. * Assuming that proteins provide $12.5 \%$ of the total calories; ${ }^{\#}$ assuming that proteins provide $15 \%$ of the total calories.

are insufficient and the per capita resources are far below the world average. Grain security remains a critically important global strategic issue for the future, which has a bearing on national economic development, social stability and national security in China.

\subsection{China faces great pressure in guaranteeing the continuously adequate grain supply}

Over the last decade, China's grain production has been increasing annually, with the total grain production reaching $602 \mathrm{Mt}$ in $2013^{[9]}$, which was the highest level of production recorded. Concurrently, the yield of grain crop per unit showed logarithmic growth; the yield of the grain per unit continues to increase and variation in yields decreased gradually. This indicates that to achieve an increase in grain yield per unit area will become increasingly difficult ${ }^{[14]}$. It can thus be seen that China faces great pressure to enhance grain production. The three main factors that restrict the increase of grain production are as follows.

\subsubsection{High rate of loss of cultivated land resources}

Cultivated land is the basis of food production as it produces grain directly and provides various meat and milk products indirectly via the feed use pathway. Firstly, the quality of cultivated land is being seriously degraded and this degradation poses a clear threat to the stability of grain production. Overuse of land and man-made emissions of waste gas, waste water and other wastes destroy the nutritive materials in the soil, resulting in the degradation of farmland. Currently, degraded farmland accounts for over $40 \%$ of the total cultivated area in the country ${ }^{[15]}$. Secondly, the quantity of farmland is reduced. As the economy is developing and the ratio of urbanization is increasing, a large amount of agricultural land is transformed into urban land and farmland per capita declines. $\mathrm{Mu}$ et al. pointed out that the farmland per capita in China declined from $0.10605 \mathrm{hm}^{2}$ in 1996 to $0.10138 \mathrm{hm}^{2}$ in $2009^{[16]}$. In the investigation conducted by Liu Jinghui, it was found that medium and high-production farmland contributed more than $80 \%$ of grains ${ }^{[17]}$. There- 
fore, the present low population-carrying capacity of farmland in China is a serious problem, which limits the development of China's agriculture as well as the increase of protein production.

2.1.2 Water resources are in short supply and unevenly distributed

China is a country with relatively scarce water resources which, on a per capita basis, are only equivalent to $28 \%$ of the world average. Also, national water resources are unevenly distributed, with water and soil resources being severely misaligned. Northern farmland area takes up $60 \%$ of the national farmland area while water resources only account for $20 \%$ of the national total ${ }^{[18]}$. Finally, with the increase in domestic and industrial sewage, available water resources for irrigation further decline. Wang et al. found serious problems contributing to agricultural water shortage and pollution which would restrict the development of agriculture ${ }^{[19]}$. Thus, water resources have a serious influence on the stability of grain production, further influencing protein security in China.

\subsubsection{High dependence on imported protein}

Over recent years, feed resource shortage has become a limiting factor for China's feed and breeding industries, and the dependence on imported protein feed resources country increases annually. Soybean and fish meal are the main proteins in good supply for quality feed, but these are lacing in China and must be imported in large amount. In 2013 , domestic production of soybeans was $12.6 \mathrm{Mt}$ and imports were $63.4 \mathrm{Mt}$, meaning the dependence on imported soybean was $83.9 \%{ }^{[20]}$. During the period from 2004 to 2010, the external dependence of China on fish meal remained above $70 \%{ }^{[21]}$. Thus, protein supply in China showed obvious characteristics of limited domestic production growth, sharp increase of imports, and high foreign dependence.

\subsection{Demand for protein in China increases annually}

With growth of population, rising incomes, and promotion of urbanization, total demand for food proteins in China increases annually.

Firstly, the population is growing and the economy is developing. China's population increases on average by 12 million per year and the demand for proteins increases about $0.3 \mathrm{Mt}$, equivalent to $1.3 \mathrm{Mt}$ of pork. At the same time as growth in population, urbanization directly promotes a change in nutritional and dietary patterns, thus increasing the demand for proteins per capita ${ }^{[22]}$. Hence, population growth and urbanization are becoming increasingly important factors influencing the demand for proteins in China.
Secondly, the consumption of proteins of high biological value is increasing. With increased food consumption and improved consumption structure, China's consumption of animal proteins has grown rapidly ${ }^{[23]}$. In 1990, China consumed meat products, aquatic animal, and milk of 25.3, 12.5 , and $4.2 \mathrm{Mt}$, respectively, and 71.0, 64.9, and $47.9 \mathrm{Mt}$, respectively, in 2013. From 2010 to 2012, the average growth rate of feed production reached $8 \%[24]$, while the growth rates of grain were only $2.9,4.5$, and $3.2 \%{ }^{[25]}$. The growth rate of feed grain greatly exceeded that of grain production in the same period, which has exerted great pressure on grain production, feed grain supply and food security in China.

2.3 Improvements in storage, transportation, and processing technology for protein production

Currently, there are mainly three aspects affecting China's protein resource development and utilization. Firstly, losses occur during grain preservation, transportation. Secondly, the contribution of protein processing technologies to both resource and the overall utilization rate are both relatively low. Finally, there is considerable wastage of food resources during utilization.

\subsubsection{Serious post-harvest loss of grain}

Post-harvest loss of grain is an issue that cannot be ignored and requires an urgent solution. Looking at the domestic and international conditions of food utilization, a large amount of food is not stored or transported appropriately after production. Loss and waste inevitably occur during harvesting, purchase, transport, storage, processing and consumption of food. China's loss rate at all stages is shown in Fig. 1, with the overall loss rate reaching 16\%$22 \%{ }^{[26]}$. Considering just the storage, transport and processing, the total amount of grain loss and table waste after production reached $122 \mathrm{Mt}$ (in 2012, China's total grain production weighed $590 \mathrm{Mt}$ ), taking up $21 \%$ of the country's total production in $2012^{[27]}$.

\subsubsection{Low overall utilization rate}

At present, the utilization rate of protein resource in mainland China is relatively low. Plenty of by-products that are rich in protein are not fully utilized, either being thrown away or used as fertilizers, which causes a huge wastage of protein resources. For instance, around $10 \mathrm{Mt}$ of rapeseed cake (the byproduct of oil extraction) is produced annually in China, only $42 \%$ of which is used as fodder. The annual production of cottonseed meal is around $5 \mathrm{Mt}$, only $30 \%$ of which is used for feed and most of which is used as fertilizer. On the whole, the efficiency of transforming feed into protein is low, thus causing huge wastage of feed protein resource. Taking broiler and pig 


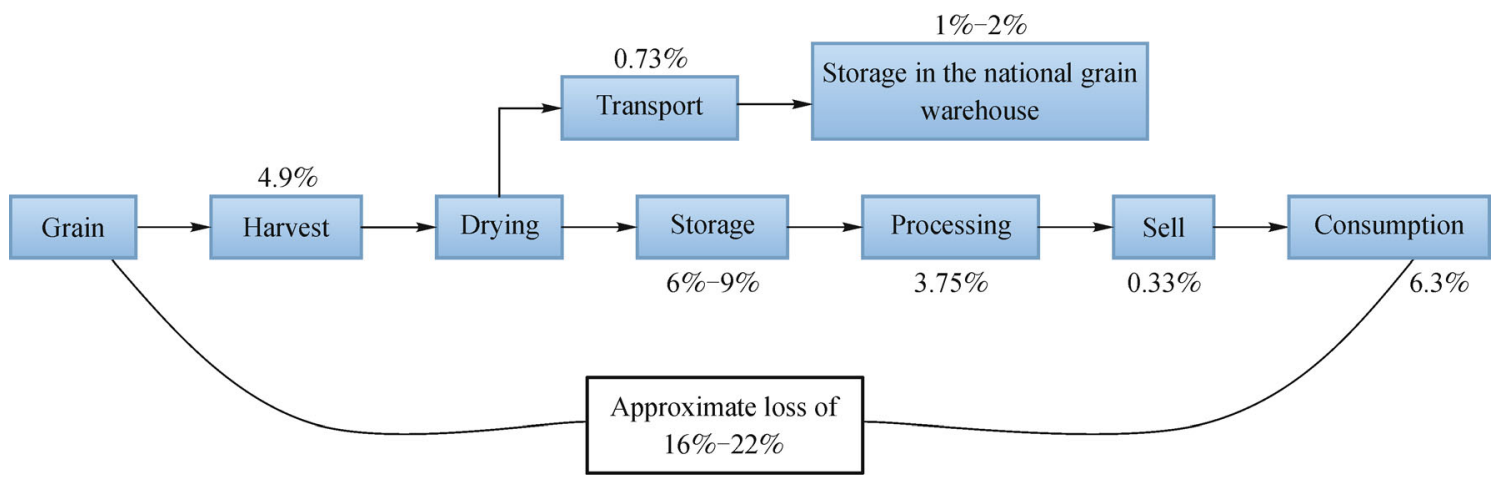

Fig. 1 Loss rates at each stage of food production and consumption

feed, as examples the efficiency of transforming feed into protein in the United States is respectively $18.8 \%$ and $25.0 \%$ higher than $\mathrm{China}^{[28]}$. Thus, an effective way to solve the issue of China's protein security is to achieve high-value, resourcing and ecological utilization of lowvalued biological protein by using high-tech means, to eliminate toxins and anti-nutritional factors and to provide a balance of dietary amino acids.

\subsubsection{Food contamination wastes precious protein}

Ever since China's economic reform and liberalization, the overuse and improper use of pesticides, veterinary drugs and additives has resulted in excessive residues of toxic and harmful substances in agricultural products. Also there has been a series of food safety incidents, such as poisonous milk powder, illegal cooking oil, tainted steamed buns, water-injected meat and the like. These not only affect the intake of the nutritional components in food, but more importantly, cause severe damage to human health ${ }^{[29]}$. In 2008, the melamine incident caused over $100 \mathrm{kt}$ of inedible tainted milk powder, which is a good example of protein waste, indicating how food safety events can cause protein loss or weaken its nutritional impact. Such food safety events in China affect protein supply or edible value.

2.4 Out-of-balance dietary structure lowers food's nutritional value and damages human health

Chinese dietary structure is out-of-balance in the country. The distribution situation of consumed protein is also dramatically different for people in economically developed or developing areas. According to an investigation conducted by He Yuna and the others, in 2002, the ratio of calories originating from fat already reached $35 \%$ of the total calories consumed by China's urban residents, exceeding the $30 \%$ upper limit recommended by the World Health Organization (WHO). The proportion of calories from protein was around $11.8 \%$ of the total calories. Among urban dwellers, energy provided by cereals was $48.5 \%$ of the total calories, obviously lower than the recommended range of 55\%-65\% and the $61.5 \%$ for rural residents ${ }^{[30]}$. These data illustrate that urban residents take in excessive fat, insufficient protein and too little carbohydrate. When taking into consideration the regional differences and income gaps, food protein intake is woefully inadequate in some regions. For dwellers in big cities, $49.4 \%$ of the protein comes from the high-quality protein contained in beans and animal food, while in the countryside, the percentage ranges between $17.1 \%$ and $28.0 \%$, which seriously influences the health of rural people.

\section{Suggestions for ensuring food and protein security}

3.1 A small increase in total grain production and progressive adjustment to the proportion of animal and plant protein

Guaranteeing grain security is a strategic problem for a country's social stability and national self-sufficiency. Total grain production can be increased slowly and steadily through policy guidance, meticulous management, technological contributions, and capital-driven means. According to our forecast, even though the population will increase by $13.7 \%$ (up to 1.515 billion), China can supply $100 \%$ of the carbohydrate and $95 \%$ of the fat. Tang predicts that, by $2030,1.515$ billion people may need $586 \mathrm{Mt}^{[31]}$ of grain, and the estimate is calculated at $650 \mathrm{Mt}$ using the econometric methods.

Multiple methods are needed to increase the quantity of protein supply, such as increasing the yield of feed grain, increasing the proportion of non-grain fodder through science and technology, and improving the efficiency of transforming feed into animal protein. The food security 
policy in China can be refined as the need for protein security. This viewpoint is more intensive and scientific than Pan's presentation that China's grain problem is mainly the feed grain problem ${ }^{[32]}$. Therefore, China should ensure the quantity of animal protein transformed from grain or non-grain fodder is sufficient and improve the conversion efficiency.

3.2 Promoting the application of technologies for protein extraction and processing

Intensifying the development and utilization of existing protein resources is the most effective way to guarantee protein security in China. Efficient use of existing technology and the development of new technology could vastly improve the nutritional characteristics of protein resources and enhance the digestibility and use efficiency of protein, effectively removing the toxic and harmful substances, and realizing the goal of saving resources and improving nutrition, food safety and environmental protection. The application of new and high technology such as shell removal, extrusion and expansion, fermentation, ultrafiltration, and superfine grinding can increase the amount of protein extracted from bean pulp, rapeseed meal, cottonseed meal, and other protein resources with high protein content by over 10.5 Mt. Chen et al. found that the functional indices of corn gluten meal after extrusion can be improved significantly, in addition the color, smell and water solubility of the products can also be improved, protease inhibitor activity inhibited, and digestibility and use efficiency raised ${ }^{[33]}$. Science and technology has a considerable prospect for maximizing the potential of protein resources, and is one of the most effective ways to relieve China's protein safety problems.

\subsection{Adjustments to dietary patterns and promotion of} nutrition security

Grain, nutrition and food security is a great challenge for all parts of the world. In October 2012, the Committee on World Food Security suggested to replace "grain security" with "food and nutrition security," which reflected the rising awareness of this issue at the international level. Chinese people can adopt more balanced dietary patterns to improve the biological value and nutritive value of protein. Eating two or more kinds of protein sources can provide a balance of essential amino-acids for the human body and thus improve the biological value of protein. For example, when eating either bean curd or wheat gluten separately, the biological values of the two are 65 and 67 respectively. But when eating them with a proportion of 42 to 58 , the biological value is increased to $76^{[34]}$. Advocating a mixed diet of meat and vegetables in our daily life can adequately supplement the value of protein (or limiting amino acids) and make the amino acids or polypeptides in the food more easily absorbed, thus achieving better nutritional and health outcomes.

\subsection{Raising awareness of nutrition and improving consumption habits}

China should effectively improve people's cognitive level of nutritional knowledge, gradually popularize the use of nutrition labeling, and adequately promote understanding of the properties of food through the popularization of science and the power of mass media. Furthermore, China should raise people's awareness of nutrition, correct bad eating habits, improve the dietary patterns, and enhance the health literacy by intensifying education concerning a scientifically-based diet ${ }^{[35]}$. In addition, China needs to guide the consumers to consume scientifically and rationally, oppose wasteful behavior and change bad consumption habits ${ }^{[36]}$.

\section{Conclusions}

From the perspective of nutritional requirements and food quality, the supply of fat and carbohydrates from China's domestic agricultural production can meet the nutritional requirements of a population up to 1.515 billion. The grain security issue is, in essence, dependent on protein production and supply, especially proteins of high biological value or animal protein. Therefore, the food security policy in China can be refined as an issue of protein security. The potential increase in the amount of protein $(9.27 \mathrm{Mt})$ produced by processing and preserving techniques can replace $80.5 \%$ of imported protein. A number of measures should be adopted to raise people's awareness of nutrition and improve their consumption behavior to achieve best practice in use of precious protein resources.

Acknowledgements This research was financially supported by Consulting Research Foundation of Chinese Academy of Engineering (2015-XY-41).

Compliance with ethics guidelines Zheng Ruan, Shumei Mi, Yan Zhou, Zeyuan Deng, Xiangfeng Kong, Tiejun Li, and Yulong Yin declare that they have no conflict of interest or financial conflicts to disclose.

This article does not contain any studies with human or animal subjects performed by any of the authors.

\section{References}

1. Fullbrook D. Food as security. Food Science and Technology, 2010, 2(1): 5-20

2. Fu G H. Study on the multi-dimensional costs of food production in China and an analysis of the new guarantee mode of China's food security. Dissertation for the Doctoral Degree. Beijing: China Agricultural University, 2014 (in Chinese)

3. National Bureau of Statistics of the Peoples' Republic of China 
(NBS). The second census. Available at NBS Website on June 20, 2015

4. Kim I Y, Schutzler S, Wolfe R, Ferrando A. Quantity of dietary protein, but not pattern of intake, affects net protein accretion in older adults. The FASEB Journal, 2014, 28(1): Supplement 272.4

5. Chen C.The research of China's international status in edible oil market and the import security. Dissertation for the Master Degree. Hangzhou: Zhejiang University, 2011 (in Chinese)

6. Li N, Dong Y B. Oilseeds and edible vegetable oils market situation in 2013 and their prospects in 2014. Agricultural Outlook, 2014, (3): 9-14 (in Chinese)

7. He W. The influence factors and trade potential of oilseed trade in china: a gravity equation analysis. Dissertation for the Doctoral Degree. Beijing: Chinese Academy of Agricultural Sciences, 2011 (in Chinese)

8. Deng R. Development of poultry industry in China. Dissertation for the Doctoral Degree. Beijing: Chinese Academy of Agricultural Sciences, 2003 (in Chinese)

9. Wen F R. Research on corn industry competitiveness of Shandong province. Dissertation for the Doctoral Degree. Taian: Shandong Agricultural University, 2014 (in Chinese)

10. Yang L, Hua D. Study on the risk analysis and the risk assessment index system of grain security in China. Research of Agricultural Modemization, 2014, 35(6): 696-702 (in Chinese)

11. Yu Z. The quantitative analysis and policy options of China's macro-control of the grain. Dissertation for the Doctoral Degree. Changchun: Jilin University, 2012, (in Chinese)

12. Zhong Y, Zhang H. Impact of China's grain import on grain security in recent years. Agricultural Outlook, 2014, (4): 59-65 (in Chinese)

13. Wang X. The influence of the essential amino acids for human body health. China's Food and Nutrition, 2005, 7: 48-49 (in Chinese)

14. Zhang R F, Yan C R, Zhang N, Li J, Sen Q R. Studies on microbial fertilizer and its application prospects in improving arable land quality. Journal of Agricultural Science and Technology, 2013, 15 (5): 8-16 (in Chinese)

15. Wang J H. Environmental and ethical issues in use of cultivated land in agricultural production. Journal of Agricultural Science, 2014, 42 (6): 1820-1822

16. Mu H Z, Zhang W X. A study of the population survival coefficient of arable land resources of China. Population Study, 2014, 38(3): 14-27 (in Chinese)

17. Liu J. Studies on technical strategies of China's food security. Dissertation for the Doctoral Degree. Beijing: China Agricultural University, 2002 (in Chinese)

18. Ding R S. Development and application of non-full irrigation management information system for north areas. Dissertation for the Master Degree. Xianyang: Northwest A\&F University, 2005 (in Chinese)

19. Zhang C L, Fu Y C, Zang W B, Zeng Q, Sun F Q. A discussion on the relationship between water shortage and poverty in China. Rural Water Resources of China, 2013, (1): 1-4 (in Chinese)
20. Xu N, Fu D, Hao J, Gu Y. The study on the countermeasures and the influence of soybean imports on the industrial security of soybean in China. Food Research and Development, 2014, 35(18): 327-329

21. Dai Y J. Early waring of imported fish meal's price risk. Dissertation for the Master Degree. Shanghai: Shanghai Ocean University, 2011 (in Chinese)

22. Li Z M. Study on the development of food consumption and nutrition between urban and rural residents in China. Dissertation for the Doctoral Degree. Beijing: Chinese Academy of Agricultural Sciences, 2007 (in Chinese)

23. Si Z S. Study on meat supply and demand with the goal of nutrition in China. Dissertation for the Doctoral Degree. Beijing: Chinese Academy of Agricultural Sciences, 2012 (in Chinese)

24. Li Y H, Zhang X M, Li B J. A forecasting model for China's feed grain demand based on system dynamics approach. Henan Science, 2012, 30(1): 127-130 (in Chinese)

25. Jiang X. Study on China's food security and the " Three Rural Issues”. Journal of Shanxi Agriculture, 2014, 42(8): 771-785,791 (in Chinese)

26. Wang Y. Research on development of the grain logistics in Heilongjiang reclamation area. Dissertation for the Master Degree. Haerbin: Northeast Agricultural University, 2013 (in Chinese)

27. He J. Analysis of effectiveness of Chinese food waste containment measures at present stage. Business, 2014, (5): 197-201 (in Chinese)

28. Cui L. Agricultural products over processing to staggering losses, improve the comprehensive utilization rate to extremely urgent. Agricultural Engineering Technology, 2014, (8): 21-25 (in Chinese)

29. Sun J J, Zeng L L. China food security situation analysis and countermeasures. Food Research and Development, 2012, 33(6): 233-235 (in Chinese)

30. He Y N, Zhai F Y, Wang Z H, Wang H J, Hu Y S, Yang X G. The status and trend for dietary pattern of energy, protein and fat in Chinese residents. Acta Nutrimenta Sinica, 2004, 27(5): 358-361, 365 (in Chinese)

31. Tang H J. The analysis of the grain supply and demand balance in mode of Chinese rational diet. Agricultural Economic Problems, 2012, 9: 4-11 (in Chinese)

32. Pan Y G. Increase the proportion of feed grains, China's food security will be higher. China Feed, 2006, (22): 15-17 (in Chinese)

33. Chen R Z, Meng F L, Zhang S Q, Liu Z Q, Bai H L. Study on high pressure extraction technology of a stragaloside IV from radix a stragali. Chinese Pharmaceutical Journal, 2008, 7: 519-524

34. Hu S. Scientific Collocation- improve biological value of dietary protein. Cooking Knowledge, 2006, (5): 35-36 (in Chinese)

35. Wang Y. Study on the goal of grain production based on nutritiondemand. Dissertation for the Master Degree. Beijing: China Agricultural University, 2013 (in Chinese)

36. Wang S X, He Y Q, Wang X D, Wang S J. Building low-carbon consumption pattern in China in the era of low-carbon economy. Soft Science, 2010, 7: 54-57 (in Chinese) 